\title{
Brand Loyalty and The Moderating Role ofInvolvement: A Strategic Alliance Perspective in Indonesia Airline Industry
}

\author{
Anggun Pratama and Rizal Edy Halim \\ Faculty of Economics and Business, Universitas Indonesia. \\ Correspondence author Email: rizaledy@gmail.com
}

\begin{abstract}
This research topic is about the membership of Garuda Indonesia (the biggest airline in Indonesia) into SkyTeam airlines alliance. This study aims to examine the influence of strategic airline alliance on the brand loyalty of Garuda Indonesia's passengers in Indonesia. This research will examinethe relationship between strategic airline alliance, brand equity, brand preference and brand loyalty with a moderation effect of involvement on the relationship between strategic airline alliance and brand equity, and the relationship between brand preferences and brand loyalty. In particular, for both low and high involvement passengers, the effect of global airline alliances on brand equity, and brand preference on brand loyalty will be also examined by using structural equation model and multi-group method analysis. Data for this research were collected from Garuda Indonesia consumers, specifically those who have flown with Garuda Indonesia. They were then analyzed using Structural Equation Modelingand multi-group analysis method. The result on total sample of this research showed that all independent variables have significant effect to all dependent variables. However, in multi-group analysis, for both low and high-involved passengers, brand equity did not affect brand loyalty. Meanwhile, in other multi group analyses, all groups showed an effect on the relationship.
\end{abstract}

Keywords: global airline alliances, brand equity, brand preference, brand loyalty and product involvement.

JEL Classifications: C31, D11, D12, M31

\section{INTRODUCTION}

International strategic alliances have occurred in a broad spectrum of industries including the automobile, commercial aircraft, electronics equipment, steel, and telecommunication industries (The Economist, 11 September 1993). While the airline sector is a mature industry in which a wide range of competitive practices reflects highly intense levels of rivalry. In order to attract more passengers in an increasingly competitive environment, international airlines have been seeking to extend the range of their network and access new markets. As operating in the commercial airline industry becomes increasingly more challenging, more airlines have sought to join one of the three existing global strategic alliance networks; one- world, Star Alliance, and SkyTeam (Tugores-García, 2012). These networks provide their members with a rich international route portfolio that would be difficult to be reached through organic growth at a marginal cost. These strategic alliances, along with a portfolio of coordinated synergies, have already impacted on the operations of the airlines worldwide. Being part of a multilateral alliance allows airlines to access markets and resources otherwise not attainable due to current geographical and regulatory constraints (Gudmundsson and Lechner, 2006). 
Since one of the most important roles of airline alliances is to provide values to their consumers (Kleymann and Seristö, 2004), it is crucial to investigate how consumers perceive thevalues of airline alliances. Studies suggest that the consumer's perceptions of the benefits offered by global airline alliances remain uncertain and are often neglected (Weber, 2003). As the diversity of airline services and the level of competition in the airline industry increases, consumers can switch among airlines more easily now compared to the past. Airlines that respond sluggishly to the changes will certainly suffer the consequences. As suggested by Mittal (1995), product involvement refers to the perceived importance of a specific product or service based on consumer requirements, values and interests. The consumer's levels of involvement can vary depending on product or service categories (Bloch and Richins, 1983). Involvement with a product has been hypothesized to lead to a greater perception of attribute differences, perception of product importance and greater commitment to brand choice (VonRiesen and Herndon, 2011). Passengers with different degrees of involvement usually perceive values for airline alliances differently (Janawade, 2013).

Some scholars have considered the consumer's perception of airline alliances benefits and loyalty programs (Goh and Uncles, 2003). Weber (2005) looked at the consumer perceptions of airline alliance service performance, and failure and recovery issues. Tsantoulis and Palmer (2008) and Tiernan et al. (2008) examined airline alliance quality convergence and performance levels while Janawade (2013) investigated the attributes of consumer perceived value of airline alliances and the services that influence consumers. Kalligiannis (2009) investigated the impacts of the individual brands of airlines that participate in global alliances and their alliance brands and reported inconsistencies in the findings regarding branding issues.

However of all these studies on the consumer's perception of airline alliances benefits, very few have examined the issue in terms of branding. In such situations, having solid brand management strategies is becoming more and more important (Budiarti et al., 2013). In Indonesia itself, it's the first time for the industry to havethis kind marketing phenomenon and given the increasing importance of global airlines alliance topic, airline alliance brand equity and the relationship with brand preference and loyalty to brand from the perspective of consumers deserve more thorough investigations (Kalligiannis et al., 2006). Thus, thisstudywillbe conducted to examine the influence of membership of Garuda Indonesia into SkyTeam alliance to their brand equity, brand preference and brand loyalty from its customer perspective.

Conceptual Background\&Hypotheses. The effects of international airline alliances have previously been investigated elsewhere. In particular, Brueckner and Whalen (1998) examined whether alliance partners charge lower interline fares than non-allied carriers. They found that an alliance between two previous competitors would raise fares by about $5 \%$ in their gateway markets, but the effect is not statistically significant. Park and Zhang (2000) investigated alliance effects on airfares, passenger volume, and consumer surplus in North Atlantic aviation markets. They found that, on average, output increases and airfares fall on the routes served by carriers entering airline alliances. Prior studies have shown that consumers generally believe that same-carrier connections (1) involve shorter distances between gates in the terminal, thus making transfers to connecting flights easier, and (2) are less likely to result in lost luggage (DOT, 1986). In addition, airlines prefer to offer connecting flights as on-line because CRSs, especially those in the USA, 
list on- line flights before interline connections on CRS display screens, and travel agents tend to book customers on flights listed on the first screen. In Taiwan, two Taiwanese leading airlines China Airlines and EVA Air recently refreshed their brand image through joining SkyTeam and Star Alliance, respectively. After joining the alliances, both airlines enjoyed a boost in passenger volume and annual revenue. Button et al. (1998) suggested a number of possible reasons for alliance formation. These are cost savings, market penetration and retention, financial injections, infrastructure constraints, and circumventing institutional constraints and market stability. They argued that joining an airline alliance allows major carriers to spread their brand name and generate revenues on thin routes without a commitment of major capital investments. Furthermore, an alliance may also involve a series of joint agreements relating to sales and marketing; purchasing and insurance; catering; ground handling; and aircraft maintenance.

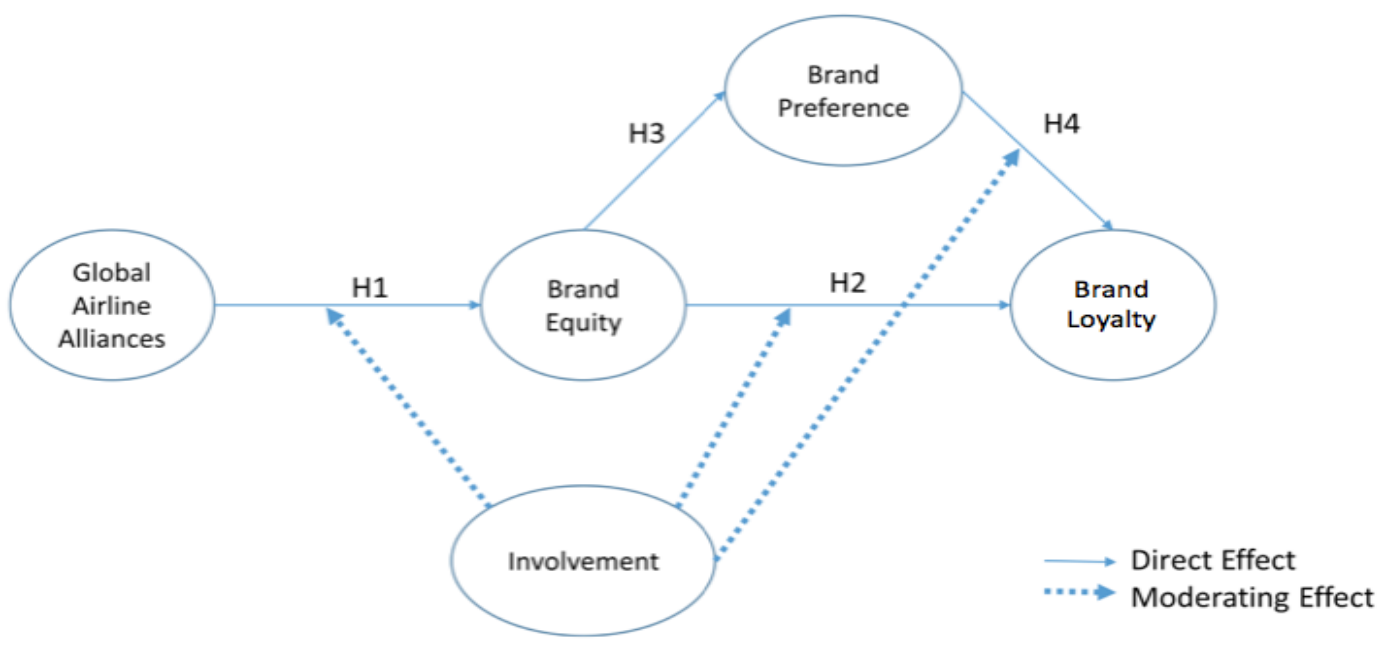

Figure 1. Research Model

Oum et al. (2004) reported that horizontal alliances make a significant contribution to productivity gains, while finding no overall significant and positive impact on profitability. Hsu and Shih (2008) found that alliances effectively improve accessibility from high medium traffic airports to low traffic airports, and particularly the shortest paths between origin destination pairs will involve more transfers but less travel time after an alliance is formed. Goh and Uncles (2003) found that, through using the services from an airline that joins global airline alliance, travelers get greater network access; seamless travel; transferable priority status; extended lounge access; and enhanced frequent-flier program (FFP).Weber (2005) suggested that convenience is the main factor contributing to traveler perceptions of the importance of airline alliance benefits rather than the ability to earn frequent flyer points and an expanded route network. Janawade (2013) found that the co-operative, collaborative, interactive, reciprocal and coherent services influence the consumers' perceived value of airline alliances. The differentiation strategies with global airline alliances from the consumer's perspective and the differences among the three global airline alliances in terms of their consumers' perceived value, which sequentially affect consumers' attitudes toward choice of airline. Despite the aforementioned studies, there are relatively few studies of global airline alliances incorporating performance outcomes. Moreover, studies of global airline 
alliances have been focused mainly on strategic and operational issues pertinent to the firm. Much less attention has been given to the consumer perspective.

Most recently, several studies have dealt with consumers' evaluation of brand alliances, focusing mostly on positive effects of brand alliances on the members' brand equity (Washburn et al. 2004; Halim and Zulkarnain, 2017). Rao and Ruekert, (1994) found that brand alliances can increase perceived quality of a weak brandespecially in case of a service brand with an unobservable quality. In general, a second brand (alliance) provides additional information for potential customers (Abratt and Motlana 2002). In this respect, the fact that the stronger brand (alliance) is perceived to be willing to use its own reputation is accounted for a stronger signal of quality for a weaker brand (Rao et al. 1999, Park et al. 1996, Wernerfelt 1988) where in this case is the alliance members. Therefore, Rao et al. (1999) propose that weak brands (for this study is Garuda Indonesia) should join alliances of strong brands. Drawing on Simonin and Ruth (1998), it can be assumed that each partner's brand (i.e. also the strong brand) can benefit from spillover effects deriving from consumer attitudes towards the brand alliance.

In the case of airline alliances, network membership promises a number of additional benefits for travelers. Among the most cited ones in the literature are the extended number of connections, improved airport transfer processes and improved frequency of services (Weber 2005). Going along with increased safety standards (as a condition for membership), and the extension of frequent- flyer programs from single airlines to the entire network, it could be assumed that the utility of flying with a network member is likely to be higher than with a single airline. Nevertheless, empirical evidences of consumers' perceptions in the specific case of airline alliances are scarce (Weber 2002). Goh and Uncles (2003) found that travelers basically are aware of most of these benefits, especially concerning improved network access and frequent flyer program advantages. In an intercultural study conducted by Weber (2005), easier transfers between flights, smoother baggage handling and one-stop check-ins were identified as most important advantages for travelers.

Drawing on signaling theory, it can be supposed that a reputable network brand (alliance like SkyTeam) can successfully strengthen of signal information that a weak brand could not communicate itself (Rao and Rueckert 1994, Gammoh et al. 2006; Halim, 2017). Empirical findings on the brand-alliance phenomenon (e.g. Gammoh et al. 2006, Rao and Rueckert 1994, Rao et al. 1999, Simonin and Ruth 1998) validate this interrelation. Thus, we propose that the announcement by an airline that it will be joining a well-known, reputable network, should lead to a more positive evaluation of the airline's brand image and its brand equity. However, empirical findings also suggest that established brands can be quite resistant to change (c. f. Keller and Aaker 1992; Lane and Jacobson 1997). In line with these findings, researcher expects the positive effect of airlines alliance network to be stronger for its member than for not-member airlines brands. The brand alliance, thus, will act as an endorsement for the unknown brand (Gammoh et al. 2006).

$\mathrm{H} 1$ :Brand equity is positively influenced by global airline alliances and this relationship is moderated by the level of involvement.

Previous research has established a positive effect of brand equity on consumer preference and brand loyalty (Cobb-Walgren et al., 1995). Several studies attempted to conceptualize and measure brand equity. Brand equity constructs identified include awareness, associations, perceived quality, and loyalty, among others. Brand loyalty 
represents the core of a brand's equity. Daryl Travis on OvidiuIoanMoisescu (2007) consideredbrand loyalty as"the ultimate objective and meaning of brand equity", adding that "brand loyalty is brand equity". Still, brand loyalty can not be analyzed without considering its relationship to other descriptive dimensions of brand equity like awareness, perceived quality, or associations. Firstly, all the other descriptive dimensions of brand equity can enhance brand loyalty, as perceived quality, associations and awareness provide reasons to buy and affect satisfaction. Loyalty could arise from a brand's perceived quality or associations, but could also occur independently of these dimensions (for example, a person can be loyal to a low perceived quality brand and dislike a brand with a high perceived quality due to subjective reasons). Yet, the nature of this relationship is unclear. As a conclusion, brand loyalty is both an input and an output of brand equity and it is both influenced by and influences the other descriptive dimensions of brand equity.

$\mathrm{H} 2$ :Brand loyalty is positively influenced by brand equity and the level of involvement moderates this relationship.

Cobb-Walgren et al. (1995) used two sets of brands, one from a service category (hotels) characterized by fairly high financial and functional risk, and one from a lower risk product category (household cleansers) to conduct two separate studies. Across categories, the brand with the higher equity in each category generated significantly greater preference and purchase intentions. Myers (2003) employeda longitudinal study to investigate the impact of brand equity on brand preference. The study, conducted on the high involvement soft drink category, showed a strong relationship between brand equity and brand preference. Other researchers, like Prasad and Dev (2000), pointed out that high equity is associated with high customer satisfaction, brand preference, and loyalty; high guest retention; high market share; a price premium; high profits; and, finally, high share values.

This study utilizes brand preference as the primary factors affected by distribution intensity and other brand equity constructs. Several empirical studies in the literature supported the positive relationship between brand equity constructs and brand preference (Cobb-Walgren et al., 1995; Agarwal \& Rao, 1996; Vakratsas\& Ambler, 1999; Mackay, 2001b; Myers, 2003; Lavidge, 1961). Further, Agarwal \& Rao (1996) developed a model that links brand equity to the hierarchy of effects model. Customer-based brand equity has been thought of as a prerequisite to brand preference, which in turn affects consumers' intention to purchase. Brand equity models assessed the impact of individual measures on market share, and utilized several brand equity constructs: awareness, familiarity, weighted attributes, value for money, and overall quality of the brand (Mackay, 2001b). Therefore, brand equity constructs are expected to affect brand preference; and the challenge is to determine which constructs to prioritize in order to increase preference and improve brand performance.

$\mathrm{H} 3$ :Brand preference is positively influenced by brand equity.

Several studies emphasized the importance of brand loyalty to brand performance (Aaker, 1991; 1996; Lassar et al., 1995; Yoo\&Donthu, 1997; Chaudhuri, 1999; Yoo, Donthu\& Lee, 2000; Chaudhuri \& Holbrook, 2001; Washburn \& Plank, 2002; Balduf et al., 2003; Kim \& Kim, 2004). Chaudhuri (1999) developed a model that supports the impact of brand attitudes and brand loyalty on brand equity outcomes (market share, price, and shelf spacing). Further, Chaudhuri \& Holbrook (2001) analyzed the links between brand trust, brand affect, and brand loyalty with brand performance. 
Additionally, several studies differentiated between "Attitudinal Loyalty" and "Purchase Loyalty". (Morgan, 2000; Chaudhuri \& Holbrook, 2001) Attitudinal Loyalty isdefined as "the level of commitment of the average consumer toward the brand". Purchase (Behavioral) Loyalty isdescribed as "the willingness of the average consumer to repurchase the brand." This study focuses on the effect of brand equity constructs and brand preference on attitudinal loyalty.It is concluded that brand preference is the major actor that significantly affects brand loyalty, followed by satisfaction, affect and perceived quality.. This study advances a model that measures the effect of distribution intensity and other brand equity constructs on brand preference and brand loyalty. It was concluded that distribution intensity is indeed a major factor that drives brand preference; and ultimately brand loyalty.

H4:Brand loyalty is positively influenced by brand preference and this relationship is moderated by the level of involvement.

\section{METHOD}

In this study, descriptive research was conducted to fulfill the objective in analyzing the effect of Garuda Indonesia membership into SkyTeam strategic airlines alliance, which is described by variables of brand equity, brand preference and customer brand loyalty. There is also another variable that moderating the relationship in between namely customer involvement. The objective of this descriptive research is to help decision makers in deciding, evaluating, and selecting the best alternative to solve problems (Malhotra, 2004). The data collection was conducted through survey questionnaire technique and will be analyzed through statistic method using SPSS 17.0 and LISREL 8.51 program. Before the primary data collection, pilot test was conducted with the objective to minimize complications in the research process. The pilot test process was also used to test the respondents' comprehension toward the wording in questions and structure of the questionnaires. The respective pilot test involved 30 respondents and this number in line with recommendation from Malhotra (2007) stated that fifteen to thirty respondents are needed to test the validity and reliability of a model.

This research is a combination of replication of the previous theory and research entitled "Do global airline alliances influence the passenger's purchase decision?" by Wang, Stephen W in the journal published in March 2014, The Relationship Between The Dimension of Brand Loyalty by OvidiuMoisescu (2007)and "The Impact of Distribution Intensity on Brand Preference and Brand Loyalty" by Ahmed H. Tolba (2011).Five items wereimplemented to measure global airline alliances, which studied by Goh and Uncles (2003). To measure brand equity, three items weregained from the research of Aaker (1991). To measure brand preference, four items wereadopted and modified from the studies by Jamal and Goode (2001), and Chen and Chang (2008). To measure brand loyalty, two items weredeployed from the research of Moisescu and Allen (2010). Finally to measure involvement, researcher wereutilized the work of Zaichkowsky (1994). These all weremeasured by using a six-point Likert type scale (sixpoint semantic differential scale will be used) starts from 'strongly disagree' until 'strongly agree'. This required the respondents to indicate a degree of their loyalty using this scale.

For this research, researcher employed the non-probability sampling in which the elements in the population have no probabilities attached to their being chosen as sample 
subjects. Convenience sampling involves collecting information from members of the population who are conveniently available to provide it and allowed the researcher to gain all the data needed. In this study, the questionnairesweredistributed to whom have flown with Garuda Indonesia internationally and live in Indonesia.The sample size is also the actual number of subjects chosen as a sample to represent the population characteristics. Due to the time constraint, the researcher targetedto distribute to at least 270 questionnaires to those who hadflown with Garuda Indonesia.

\section{RESULTS AND FINDINGS}

A pilot test was conducted to check weaknesses in questionnaire's design and instrumentation and also to measure the reliability coefficient for each variable. This research used 30 respondents for its pilot test. The respondents were customers of Garuda Indonesia airlines service, primarily those who are living in Indonesia. Researcher used the pretest to analyze whether the elements of each variable, questionnaire layout, and other important features given in the questionnaire are able to represent each variable. The data collected from the pretest were analyzed using SPSS 17. The Cronbach's Alpha for all variables weregreater than 0.60 and were accepted based on the maximum Cronbach Alpha value of 0.60 specified by (Sekaran, 2003). This is an indication that the instruments used in this study were reliable. Each indicator in the questionnaire is said to be valid if the Kaiser-Meyer-Olkin (KMO) index measurement of sampling adequacy showed a number of at least 0.5 and significance of Batlett's test of sphercity lower than 0.05 .

Table 1. Validity and Reliability test

\begin{tabular}{|c|c|c|c|c|}
\hline \multicolumn{2}{|c|}{$\begin{array}{c}\text { Construct } \\
\text { (Dimensions) }\end{array}$} & KMO & $\begin{array}{l}\text { Factor } \\
\text { Loading }\end{array}$ & CA $(\boldsymbol{\alpha})$ \\
\hline \multirow{5}{*}{$\begin{array}{l}\text { Airlines } \\
\text { Alliances }\end{array}$} & AA1 & \multirow{5}{*}{0.762} & 0.919 & \multirow{5}{*}{0.878} \\
\hline & AA2 & & 0.843 & \\
\hline & AA3 & & 0.766 & \\
\hline & AA4 & & 0.785 & \\
\hline & AA5 & & 0.798 & \\
\hline \multirow{3}{*}{ Brand Equity } & BE1 & \multirow{3}{*}{0.660} & 0.764 & \multirow{3}{*}{0.698} \\
\hline & BE2 & & 0.787 & \\
\hline & BE3 & & 0.840 & \\
\hline \multirow{4}{*}{$\begin{array}{c}\text { Brand } \\
\text { Preference }\end{array}$} & BP1 & \multirow{4}{*}{0.720} & 0.880 & \multirow{4}{*}{0.887} \\
\hline & $\mathrm{BP2}$ & & 0.885 & \\
\hline & BP3 & & 0.796 & \\
\hline & BP4 & & 0.920 & \\
\hline \multirow{2}{*}{$\begin{array}{c}\text { Brand } \\
\text { Loyalty }\end{array}$} & BL1 & \multirow[b]{2}{*}{0.500} & 0.947 & \multirow[b]{2}{*}{0.880} \\
\hline & BL2 & & 0.947 & \\
\hline \multirow{9}{*}{ Involvement } & IV1 & \multirow{9}{*}{0.900} & 0.833 & \multirow{9}{*}{0.962} \\
\hline & IV2 & & 0.838 & \\
\hline & IV3 & & 0.867 & \\
\hline & IV4 & & 0.896 & \\
\hline & IV5 & & 0.875 & \\
\hline & IV6 & & 0.881 & \\
\hline & IV7 & & 0.860 & \\
\hline & IV8 & & 0.910 & \\
\hline & IV9 & & 0.940 & \\
\hline
\end{tabular}

Source: SPSS 17.0 output for pilot test, data obtained by researcher 
Measurement Model.Analysis began by checking (1) whether the T-valuesof the standardized loading factor $(\lambda)$ for one-tailed model of the observed variables are $\geq 1.645$, based on the knowledge that a 5\% significance level is used; (2) whether Standardized Loading Factors $(\lambda)$ are $\geq 0.50$ (Igbaria et al., 1997) or $\geq 0.70$ (Rigdon and Ferguson, 1991; Wijanto, 2008). In this study the researchers used the assumption from Igbaria (1997), which stated the value of the standardized loading factors must be $\geq 0.50$. A higher coefficient of reliability shows a higher consistency of the indicators in measuring its latent variables. When assessing reliability in SEM, composite reliability measure and variance-extracted measure are used.

Measurement scales and summary statistics

Airline Alliances $($ Mean $=4.64, \alpha=$ 0.89, AVE. = 0.62)

- Airline alliances provide greater network access. $(\lambda=0.72)$

- Airline alliances provide seamless travel. $(\lambda=0.84)$

- Airline alliances provide transferable priority status. $(\lambda=0.77)$

- Airline alliances provide extended lounge access. $(\lambda=0.79)$

- Airline alliances provide enhanced frequent-flier program (FFP) benefits. $(\lambda=0.83)$

Brand Equity $($ Mean $=4.59, \alpha=$ 0.9, AVE. = 0.75)

- In comparison with alternative brands, this brand is theleading brand. $(\lambda=0.78)$

- Name the brands in this product class. $(\lambda=0.86)$

- This brand provides good value for the money. $(\lambda=0.95)$

Brand Preference $($ Mean $=4.79, \alpha$ $=0.92$, AVE. $=0.75$ )

- I feel that this airline's name is appealing to me. $(\lambda=0.88)$

- I prefer this airline to other airlines of its type. $(\lambda=0.86)$

- If I want to buy an air travel product, I would prefer thisairline if everything else was equal. $(\lambda=0.85)$

- In total, I prefer this airline. $(\lambda=0.89)$

Brand Loyalty $($ Mean $=4.86, \alpha=0.94$, AVE. = 0.89)

- I am willing to recommend to others to buy this airline'sproducts. $(\lambda=0.95)$

- I am willing to repurchase this airline's products in thefuture. $(\lambda=0.94)$

Involvement $($ Mean $=4.16, \alpha=N / A$, AVE. = N/A)

- Global airline alliances are important to me. $(\lambda=\mathrm{N} / \mathrm{A})$

- Global airline alliances are interesting to me.

- Global airline alliances are relevant to me.

- Global airline alliances are exciting to me.

- Global airline alliances are meaningful to me.

- Global airline alliances are attractive notions to me.

- Global airline alliances are valuable to me.

- Global airline alliances demand certain amount ofinvolvement from me.

- Global airline alliances are necessary to me.

Structural Model.After conducting the calculation and analysis of Confirmatory Factor Analysis (CFA), the next step wasmeasuring the latent score for each latent variable. The analysis of overall model fit wasto check whether the construct model used in this research is accurate. The fit or predictive accuracy for the structural model is determined 
by the values of Chi-Square and its p-value, RMSEA, ECVI, AIC, SRMR, GFI, AGFI, NFI, NNFI, CFI, and other fit measures that are categorized as Goodness of Fit Statistics. After analyzing the overall model fit for the Research Model, the next analysis wasconducting the causal relationships of the research model. This analysis is based on the knowledge that a 5\% significance level is used, therefore resulting a critical T-value of \pm 1.645 . The $T$-value is used to analyze the effect of one latent variable to other latent variables. Based on $\mathrm{T}$ distribution table, if $-1.645 \geq \mathrm{T}$-Value $\leq 1.645$, then the coefficient structural equation is significant and the hypothesis is accepted, otherwise the coefficient of structural equation is insignificant and the hypothesis is rejected. Coefficient of determination is used to examine how far independent variables are able to explain its dependent variables. According to Joreskog (1999) and Utami (2012), in a structural equation, $\mathrm{R}^{2}$ does not have a clear interpretation, thus in order to interpret $\mathrm{R}^{2}$, reduced form equations is used.

Table 2. Comparison Model as Resulted of Moderating Variable

\begin{tabular}{|c|c|c|c|c|}
\hline \multirow{2}{*}{ Hypothesized paths } & \multicolumn{4}{|c|}{ Standardized estimate (T-Value) } \\
\hline & \multicolumn{2}{|l|}{ Sample } & High & Low \\
\hline Airline alliances ->Brand Equity & \multicolumn{2}{|c|}{$0.80(12.19)$} & $0.96(7.46)$ & $0.75(9.67)$ \\
\hline Brand equity ->Brand Loyalty & \multicolumn{2}{|c|}{$0.14(1.91)$} & $0.06(0.7)$ & $0.21(1.11)$ \\
\hline Brand equity -> Brand Preference & \multicolumn{2}{|c|}{$0.78(13.11)$} & $0.38(5.53)$ & $0.92(16.52)$ \\
\hline Brand preference ->Brand Loyalty & \multicolumn{2}{|c|}{$0.74(9.67)$} & $0.55(3.95)$ & $0.6(3.2)$ \\
\hline \multicolumn{5}{|l|}{ Fit Statistics: } \\
\hline$x^{2}$ & $\begin{array}{r}481.39 \\
(\mathrm{P}=0.0)\end{array}$ & \multicolumn{2}{|c|}{$\begin{array}{l}313.60 \\
(\mathrm{P}=0.0)\end{array}$} & $368.21(\mathrm{P}=0.0)$ \\
\hline$d f$ & 64 & \multicolumn{2}{|c|}{63} & 67 \\
\hline$x^{2} / \mathrm{df}$ & 7.52 & \multicolumn{2}{|c|}{4.97} & 5.49 \\
\hline $\mathrm{NCP}$ & 417.39 & \multicolumn{2}{|c|}{250.6} & 301.21 \\
\hline RMSEA & 0.155 & \multicolumn{2}{|c|}{0.18} & 0.17 \\
\hline GFI & 0.8 & \multicolumn{2}{|c|}{0.74} & 0.74 \\
\hline
\end{tabular}

Source: SPSS 17.0 output, data obtained by researcher

In this study, researcher is using a study method explained by Vermunt and Magidson (2002) in examining the effect of interaction of the research model with moderation variable. This method is multi group models that can be applied as a segmentation technique in order to define the optimal number of homogeneous segments on the sample market. In this application, it is assumed that the correlations between indicators (questions) are explained only by the group membership, which is a latent explanatory variable for the answering pattern. Thus, it is assumed that within the group, answers to different indicators (questions) are independent of each other. A characteristic feature of the multi group analysis is that the variable is also discrete. Grouping is designed to identify a group of individuals that possess a certain similar pattern of behavior and to test whether this pattern can be explained by the group membership. In the multi-group approach the comparison between models and the selection of the proper one can either completely formal, based on the absolute fit defined by tests of Pearson's chi-square $\left(X^{2}\right)$ 
or can be based on the information criteria and the following table summarized the data that has been found.

Based on the results, it is obvious that thereis a positive effect on group of high involvement that strengthens the relationship between global airlines alliance andbrand equity (0.80 to 0.96$)$. Meanwhile, as expected, there is a negative effect on group of low involvement in which weakens the relationship between global airlines alliance andbrand equity ( 0.80 to 0.75$)$. This contrary result is interpreted as an effect of less interested behavior of low involvement group towards the importance of airlines alliance. Meanwhile, brand equity is strongly enhanced by global airlines alliance in the perspective of high involvement group that this group is keen to look up for more detail information and believes that global airlines alliance will give more benefit in their flying experience.

Unlike the relationship between the global airlines alliance to brand equity, the other two relationships, both brand equity to brand loyalty and brand equity to brand preference, show a surprisingly unexpected results. These two relationships singularly show that there is a negative effect on group of high involvement in which weakens the relationship between brand equity andbrand loyalty (0.14 to 0.06$)$ and between brand equity andbrand preference (0.78 to 0.38$)$. On the same contrary, the group of low involvement showsa positive effect in which strengthens the relationship between brand equity andbrand loyalty ( 0.14 to 0.21$)$ and brand equity to brand preference $(0.78$ to 0.92 ). This phenomenon is hardly to believe since previous study explained that brand equity perfectly forced brand preference and then eventually influenced the brand loyalty.

Moreover, in other case, the relationship between brand preference and brand loyalty, for both low and high involvement, shows a negative effect in which weakens the relationship between brand preferences andbrand loyalty ( 0.74 to 0.60 for low and 0.74 to 0.55 for high involvement). Further possible estimations propose that this resultis caused by the fact that previous variable, brand equity, is having a weak influence towards brand loyalty. From the proposed model, researcher may conclude that there isno positive effect ofglobal airlines alliance to brand preference and brand loyalty that strengthens the relationships and this proposed model is only applicable in the relation of global airlines alliance to brand equity.

\section{CONCLUSION}

This research has examined the potential roles of global airline alliances in influencing brand equity, brand preference and brand loyalty from the Indonesian consumer's perspective in the case of Garuda Indonesia. To our knowledge, researcher would probably say that this is the first specific study related-to-airlines alliance that has implemented in Indonesia, since the flag carrier is still remain the one and the only airline that join the airlines alliance that celebrating its first anniversary this April 2015. According to the findings, airlines can influence consumer brand loyalty by enhancing the customer's perception of brand equity and brand preference by joining a global airline alliance. The findings also demonstrate that customer involvement in global airline alliances has significant moderating effects on the relationship between global airline alliances and brand equity, the relationship between brand equity and brand preference and the relationship between brand preference and brand loyalty. 
The results of this study significantly support to the existing literature in three unique ways, in regards of the increasing difficulty in nurturing and sustaining consumer's loyalty to a brand in the competitive Indonesian civil aviation industry. First, the model specifies how air travel service providers can enrich consumer perceptions of airlines by presenting all benefits derived from joining global airline alliance networks. The role of global airline alliances in shaping customer value and benefits has seldom been addressed, especially in immature market like Indonesia. Second, this study has further approved why air transport providers value a participation in global airline alliances by evaluating how airline alliances globally impact on customer perceived brand equity, brand preference and brand loyalty. Third, this study introduces a valueadded brand properties model for global airline alliances emphasized by consumers with different levels of airline alliance involvement in air travel.

This study concludes that joining an alliance group with a large number of members will reduce airline's performance because it has to spend a lot of money and labor on integration into the alliance group. An airline also cannot solve its problems quickly because the study results suggest that airlines have to remain in the alliance group for a certain period before membership has a beneficial effect on performance. Because of the complicated external environment, fierce competition, limited resources and restricting regulations, airlines struggle to improve their operations in certain aspects. Joining an alliance group provides airlines with an opportunity to overcome many of these problems. However, due to the limited influence of an alliance group, airlines should not consider joining an alliance group as a universal problem-solving strategy. Airlines should attach themselves to an alliance group while continuing to increase their competitive abilities and survival in order to cope with a rapidly changing environment.

\section{REFERENCES}

Aaker, D., (1991). Managing brand equity: capitalizing on the value of a brand name. The Free Press, New York.

Agarwal, M.K., Rao, V.R., (1996). An empirical comparison of consumer based measures of brand equity. Mark. Lett. 7 (3), 237 - 247.

Brueckner, J.K., Pels, E., (2005). European airline mergers, alliance consolidation, and consumer welfare. J. Air Transp. Manag. 11 (1), 27 - 41.

Budiarti, A., Surachman, Hawidjojo, D., Djumahir, (2013). Brand equity and customer satisfaction as the mediation of advertisement influence and the service quality to loyalty the passengers of international flight at Garuda Indonesia airlines. J. Bus. Manag. 9 (2), (p.1 - 15).

Chang, HsinHsin; Che-Hao Hsu; Shu Hsia Chung. (2008). The Antecedents and Consequences of Brand Equity in Service Markets. Department of Business Administration, National Cheng Kung University, Taiwan. Asia Pacific Management Review,13(3) (2008) 601-624.

Chen, C.F., Chang, Y.Y., (2008). Airline brand equity, brand preference, and purchase intentions-the moderating effects of switching costs. J. Air Transp. Manag. 14 (1), $40-42$

Cheng-Lung Wu; Andy Lee, (2014). "The impact of airline alliance terminal co-location on airport operation and terminal development".Journal of Air Transport Management, 36, $69-77$. 
Cobb-Walgren, C.J., Ruble, C.A., Donthu, N., (1995).Brand equity, brand preference, and purchase intent. J. Advert. 24 (3), 25 - 40.

Cristobal Casanueva; Angeles Gallego, (2013). Network resources and social capital in airline alliance portfolios. Tourism Management 36 (p.441 - 453).

Ebrahim, Reham. (2011). A Study of Brand Preference: An Experiential View. London: Brunel Business School - Doctoral Symposium.

Garuda Indonesia, (2014). www.garuda-indonesia.com

Goetz, C.F., Shapiro, A.H., (2012). Strategic alliance as a response to the threat of entry: evidence from airline code sharing. Int. J. Ind. Organ. 30 (6), 735 - 747.

Goh, K., Uncles, M., (2003). The benefits of airline global alliances: an empirical assessment of the perceptions of business travellers. Transp. Res. Part A: Policy Pract. 37 (6), 479 - 497.

Halim, Rizal Edy and ElszuaryAbrar Uzi Zulkarnain. (2017). "The Effect of Consumer Affinity, Ethnocentrism, and Country Image Toward Wiilingness to Buy. Journal of Distribution Science”. Journal of Distribution Science, 15(4) (April), 15- 23 .

Halim, Rizal Edy. (2017). The Impact of Trust-Distrust toward Quality of Life: The Case of Poor and non-Poor Household in Indonesia. European Research Studies Journal, XX (3A) (July), 801-819

IATA, (2013).IATA Annual Report 2013.https://www.iata.org.

Janawade, V., (2013).Consumer perceived value of international networked services: an exploratory study of the case of an airline Alliance. Int. Bus. Res. 6 (2), 20 - 42.

Jong-Han Park; Anming Zhang, (2011).Analytical models of international alliances in the airline industry. Transportation Research Part B 35 (865 - 886)

Kalligiannis, K., Iatrou, K., Mason, K., (2006). How do airlines perceive that strategic airline alliances affect their individual branding? J. Air Transp. 11 (2), 3 - 21.

Keller, K.L., (1993). Conceptualizing, measuring, and managing customer-based brand equity. J. Mark. 57 (1), 1 - 22.

Kleymann, B., (2005). The dynamics of multilateral allying: a process perspective on airline alliances. J. Air Transp. Manag. 11 (3), 135 - 147.

Kleymann, B., Seristö, H., (2004). Managing Strategic Alliance. Ashgate Publishing Ltd., Aldershot, England.

Kotler, P. (2003). Marketing Management. New Jersey: Engelwood Cliffs.

Malhotra, N. (2010). Marketing Research an Applied Orientation, 6th Ed. New Jersey: Prentice Hall.

Lin, Bo. (2013). The Effects of Joining a Strategic Alliance Group on Airline Efficiency, Productivity and Profitability. Massey University, New Zealand.

López-Bonilla, J.M., López-Bonilla, L.M., (2013).Positioning strategies of global airline alliances from the Consumer's perspective. Tour. Econ. 19 (1), 203 - 208.

Malhotra, Naresh K. (2007). Marketing Research: An Applied Orientation. 5th Ed. New Jersey: Pearson Prentice Hall.

Moisescu, Ovidiu I.; Allen, Brad. (2010). The Relationship Between Dimensions of Brand Loyalty. An Empirical Investigation among Romanian Urban Consumers. Management \& Marketing Challenges for Knowledge Society, 5 (4), 83-98.

Moisescu, Ovidiu I. (2006)A Conceptual Analysis of Brand Loyalty as Core Dimension of Brand Equity. Babes Bolyai University. Pp. 1-9. 
Oneworld, (2013).Oneworld at a Glance.http://www.oneworld.com/newsinformation/oneworld-fact-sheets/oneworld-at-a-glance/

Oum, T.H., Park, J.H., (1997). "Airline alliances: current status, policy issues, and future directions". J. Air Transp. Manag. 3 (3), 133 - 144.

Oum, T.H., Yu, C., Zhang, A., (2001). "Global airline alliances: international regulatory issues”. J. Air Transp. Manag. 7 (1), 57 - 62.

Oum, T.H., Park, J.H., Kim, K., Yu, C., (2004). "The effect of horizontal alliances on firm productivity and profitability: evidence from the global airline industry". J. Bus. Res. 57 (8), 844 - 853.

Saraswati, Batari; Hanoka, Shinya. (2013). Aviation Policy in Indonesia and Its Relation to ASEAN Single Aviation Market.Eastern Asia Society for Transportation Studies, Vol.9.Graduate School of Science and Engineering, Tokyo Institute of Technology.

Sky Team, (2013).SkyTeam\& Members fact sheet.http://static.skyteam.com/cdn1ce7cac87083289/Global/Press/Facts\%20and\%20figures/2012\%20Nov\%20Xiamen / Fact\%20Sheet\%202013\%20June.pdf

Star Alliance, (2013).Star Alliance Facts and Figures June 2013. http://www. staralliance.com/en/about/member_airlines/

Taskin, C., Akat, O., (2011). Measurement of consumer based brand equity using structural equation modeling and a research in durable consumer goods sector. Bus. Econ. Res. J. 1 (2), 1 - 16.

Tiernan, S., Rhoades, D., Waguespack, B., (2008). "Airline alliance service quality performance $e$ an analysis of US and EU member airlines".J. Air Transp. Manag. 14 (2), 99 - 102.

Tolba, Ahmed H. (2011)."The Impact of Distribution Intensity on Brand Preference and Brand Loyalty”.'International Journal of Marketing Studies. School of Business, The American University in Cairo. 3 (3), August.

Weber, K., (2003). "Consumer perceptions and behavior-neglected dimensions in research on strategic Airline alliances".J. Travel Tour. Mark. 13 (4), 27 - 45.

Weber, K., (2005). "Travelers' perceptions of Airline Alliance benefits and performance”. J. Travel Res. 43 (3), 257 - 265.

Wu, C.L., Lee, A., (2014). "The impact of airline alliance terminal co-location on airport operations and terminal development”. J. Air Transp. Manag. 36, 69 - 77.

Wang, Stephen W. (2014). "Do global airline alliances influence the passenger's purchase decision?'”Taipei: Journal of Air Transport Management, 37 (53 - 59).

Woisetschläger , David M. (2008). The "Dark Side" of Brand Alliances: How the Exit of Alliance Members Affects Consumer Perceptions. University of Dortmund.

Yang, W.C., \& Chen, J.P., (2006). "A study of the relationship between service quality and customer satisfaction with customer loyalty". Taiwan Journal of Hospitality, $3(1), 42$ - 55. 